\title{
Experience in uncertainty macroeconomic conditions and demographic factors as determinants of sharia stock portfolios in Indonesia
}

\author{
Iskandar Muda ${ }^{a^{*}}$ and Erlina ${ }^{a}$
}

${ }^{a}$ Universitas Sumatera Utara, Medan, Indonesia

\begin{tabular}{l}
\hline C H R O N I C L E \\
\hline Article history: \\
Received April 9, 2021 \\
Received in revised format May \\
272021 \\
Accepted May 272021 \\
Available online \\
May 302021 \\
\hline Keywords: \\
Uncertain Macroeconomic \\
Investment Yield \\
Government Sukuk \\
Sharia Mutual Funds
\end{tabular}

\section{Introduction}

In 2018, the key Islamic finance segments such as Islamic banking and capital markets continued to support economic growth across the globe by providing Shariah-compliant and ethical methods of financing. Regions that are home to Islamic finance activity such as the Gulf Cooperation Council (GCC) and parts of Asia have benefited significantly from the increasing availability and diversity of Islamic financial solutions to support both sovereign, corporate and household activity. Elsewhere, several advanced economies, including key financial centers, introduced benchmark-sized Islamic financing deals as a means of sovereign funding and to set the stage for future Shariah-compliant deals, including from the private sector (Malaysia World Islamic Finance Marketplace, 2014). In addition, African nations have also engaged Islamic financial services during the year for government funding and infrastructure needs, amid stronger demand for retail banking. While overall growth remained moderate, pockets of economic activity continued to expand in key real sectors such as infrastructure (including transportation, power and utilities and telecommunications), financial services, real estate and aviation. These activities continued to generate demand for financing and other related financial services, including the capital markets. In addition, important processes which facilitate the orderly functioning of the economy such as sovereign funding and financing of business and household transactions remained as important areas for Islamic finance to serve. (Tahir \& Mark et al., 2012, Abas et al., 2020; Nobi et al, 2020). The component commonly used as the main focus while assessing performance based on financial statements earnings. Many believe that this component is able to describe the

* Corresponding author.

E-mail address: iskandar1@usu.ac.id (S. Das)

\begin{abstract}
The purpose of this research is to know the influence of Uncertainty Macroeconomic and Shographic factors such as Population, Gross Domestic Product, Government Sukuk and research using a causal research design in Indonesia Sharia Insurance. The data used are used in this research is the SEM method using SmartPLS software. The results show that Population, Gross Domestic Product, Government Sukuk and Sharia Mutual Funds do not the Indonesian Financial Services Authority policy which considers Population, Gross Domestic Product, Government Sukuk and Sharia Mutual Funds for Investment Yield Sharia observe for 2 (two) years. Originality of this research is using the latest observation variable that is 2018-2019 and observation at a sharia insurance company in Indonesia.
\end{abstract}


overall economic condition as well as prospects for growth of the company in the future (Khan \& Bhatti, 2008, Gheeraert \& Weill, 2013, Kumar et al., 2019, Gwadabe \& Rahman, 2020, Wu et al., 2021 and Shen et al., 2021). Besides considering earnings, stakeholders should also think about the company's size, including the the company's scope associated with the life cycle of the company in evaluating earnings. By considering the company's size, they will have information about the company's need for facility and infrastructure procurement. Morse (2020) state when compared to the life cycle of a government, in the elucidation of the concerning Financial Balance between the Central Government and Regional Governments, it mentions a number of variables that reflect the need for the procurement of public facilities in each region, among of which are the regional size and the total population (Warde, 2000, Coibion et al., 2021, Levy, 2021; Patel \& Tsionas, 2021). In their research, Elgari (2010) states that areas with a larger regional size will certainly require a greater number of facilities to serve their society than the ones required by areas with a smaller regional size. In addition, the need for public facilities varies between regions depending on the total population (Abduh \& Azmi, 2012, Su et al., 2021; Liu, 2021). Reform the political and administrative changes, among the examples of such reform is manifested in the change in the government structure, which formerly was centralized, into a decentralized one after the enactment of the amended for the last time by the concerned regional governments. The economic goals to be achieved through decentralization are to bring about prosperity through the provision of more evenly-distributed public services and to shorten the distance between public service providers and local communities (Werde, 2000; Cihak \& Hesse, 2010, Gossling \& Hall, 2020, Pospieszna et al., 2020, Cui et al., 2021; Hohlwegler, 2021). The signaling theory describes the ways the management should give a signal to the users of financial statements (Furqani \& Mulyany, 2009; Abduh \& Chowdhury, 2012; Abduh \& Omar, 2012; Farahani \& Dastan, 2013; Faruq et al., 2017), explain that managers provide information through financial statements that they apply conservative accounting policies to produce better earnings. Regional autonomy is defined as the right, power, and obligation of autonomous regions to set up and manage their own governance-related affairs and interests of local communities in accordance with the legislation.

\section{Theory and Literature review}

\subsection{Uncertain financial system}

Phan et al. (2021) stated that the increasing trend of globalization in the financial sector, supported by technological developments in various countries, has caused the financial system to become increasingly integrated without time lag and boundaries. In addition, financial product innovations are increasingly dynamic and varied with increasing complexity. These developments can not only increase and increase the various sources of instability in the financial system, but also make it more difficult to overcome this instability (Candelon et al., 2021). This will lead to financial market instability. Identification of sources of financial system instability is generally more forward looking. This is intended to identify potential risks that will arise and will affect future financial system conditions. On the basis of the identification results, an analysis is then carried out to what extent the risk has the potential to become increasingly dangerous, widespread and systemic in nature so as to paralyze the economy.

\subsection{Sharia Mutual Fund}

Islamic mutual funds aim to raise funds from the public, which are then managed by investment managers to then invest in instruments in the capital market and money market. These instruments are like stocks, bonds, deposits, certificates of deposit, foreign exchange and short-term debt securities (Raza et al., 2021). This Sharia mutual fund is included in the open mutual fund category (collective investment contract). The level of knowledge and understanding of capital market players and investors towards Islamic principles is still lacking (Garrouch, 2021). Many of them think that these sharia principles are related and only for the benefit of Muslims. In fact, this principle is open to use by all parties. Other constraints include, among others, very limited information about the Islamic capital market, institutional patterns or institutions in the framework of supervision are still considered a disincentive by the actors.

\subsection{Basic Principles of Sharia Transactions}

Choon et al. (2021) state that the sharia mutual funds have transaction principles, namely (1) All forms of muamalah are permitted unless there are arguments that prohibit them, (2) the principle of freedom to make contracts based on agreements and obligations to fulfill the contract, (3) execution of transactions must be carried out according to the principle of prudence and is not allowed carry out speculation which contains elements of usury, gharar, maysir, and zhulm, (4) Upholding Ethics in transactions, Carrying out records (documentation) or writing, agreements/contracts for non-cash transactions. In accordance with operational principles, investment management as a mutual fund manager uses the principles of mudharabah and qiradh. This sharia mutual fund has several characteristics, first, investors as rab Al-mal share the risks experienced by the infestation manager as amil, second, the investment manager as amil does not bear the risk of loss on investment if the loss is not caused by his negligence. Profits in dala (ribh) are shared between investors and investment managers in accordance with the proportions agreed by both parties. The forms and types of mutual funds are generally divided into two forms, namely the form of corporate mutual funds (investment company) and collective investment 
contracts (unit investment trust). Types of mutual funds are divided into four, namely Fixed Income Fixed Income Fund, Equity Fund, Discretionary Fund, Money Market Mutual Funds.

\section{Material and method}

Comparative causal research is a study directed to investigate cause-and-effect relationships based on observations of the consequences that occur and look for factors that cause through the data collected. In this study the basic approach is to start with the differences of the two groups and then look for factors that may be the cause or effect of the difference. In this case there is an element that compares between two or more variables. The method of research using a causal research design in Indonesia Sharia Insurance. The data used are secondary data sourced from Financial Services Authority (OJK) Indonesia in 2018-2019. The method of analysis used in this research is the SEM method using SmartPLS software.

\section{Results and discussion}

\subsection{Results}

\subsubsection{Evaluation of Structural Model (Inner Model)}

Inner model evaluation through the bootstrapping menu also generates $t$-statistics values that will be used to test the hypothesis. The criteria are $t$-statistic $>1.66$. If the value of $t$ count $<t_{\text {table }}$ then Ho accepted and when the value of $t_{\text {count }}>t$ table then Ho is rejected which means that the variable in question there is influential which is significant. This means that the independent variables tested have an effect significantly on the dependent variable. The result of T-statistics value in the Table path coefficients is presented in the following Fig. 1:

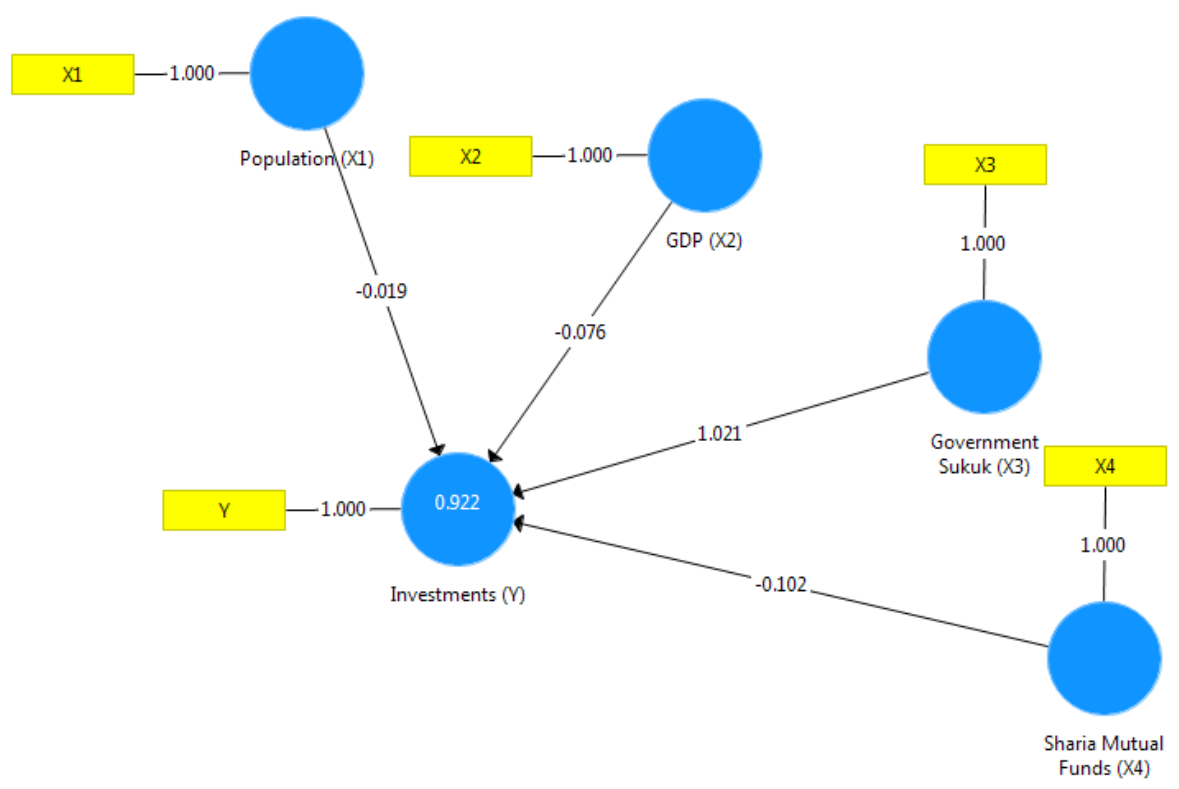

Fig. 1. Overall Model with Coefficient

Based on this model in Fig. 1, it shows that the variables used do not have a significant effect on the value of investment in sharia funds. The effect test can be seen in the following Table 1:

Table 1

The result of Bootstrapping

\begin{tabular}{cllllc}
\hline & Original Sample & Sample Mean & Standard Deviation & T Statistics & P Values \\
\hline GDP $\left(\mathrm{X}_{2}\right) \rightarrow$ Investments (Y) & $-0,076$ & $-0,107$ & 0,679 & 0,112 & 0,911 \\
Government Sukuk $\left(\mathrm{X}_{3}\right) \rightarrow$ Investments (Y) & 1,021 & 0,538 & 0,650 & 1,569 & 0,117 \\
Population $\left(\mathrm{X}_{1}\right) \rightarrow$ Investments $(\mathrm{Y})$ & $-0,019$ & 0,180 & 0,499 & 0,038 & 0,970 \\
Sharia Mutual Funds $\left(\mathrm{X}_{4}\right) \rightarrow$ Investments $(\mathrm{Y})$ & $-0,102$ & 0,214 & 0,631 & 0,162 & 0,872 \\
\hline
\end{tabular}

Sources : Smart PLS Result (2020).

Based on the above Table 1 produces a coefficient of 0.005 , smaller than $\alpha=5 \%$ then the decision of hypothesis testing rejects $\mathrm{H}_{0}$ and accept the hypothesis Ha. The results show that Population, Gross Domestic Product, Government Sukuk 
and Sharia Mutual Funds do not influence Investment Yield Sharia Insurance in Indonesia. In addition to hypothesis testing through the bootstrapping menu that produces T-statistics, inner model evaluation is also done by reviewing the R-Square value. The R-square value generated from the inner model evaluation is presented in the following Table 2:

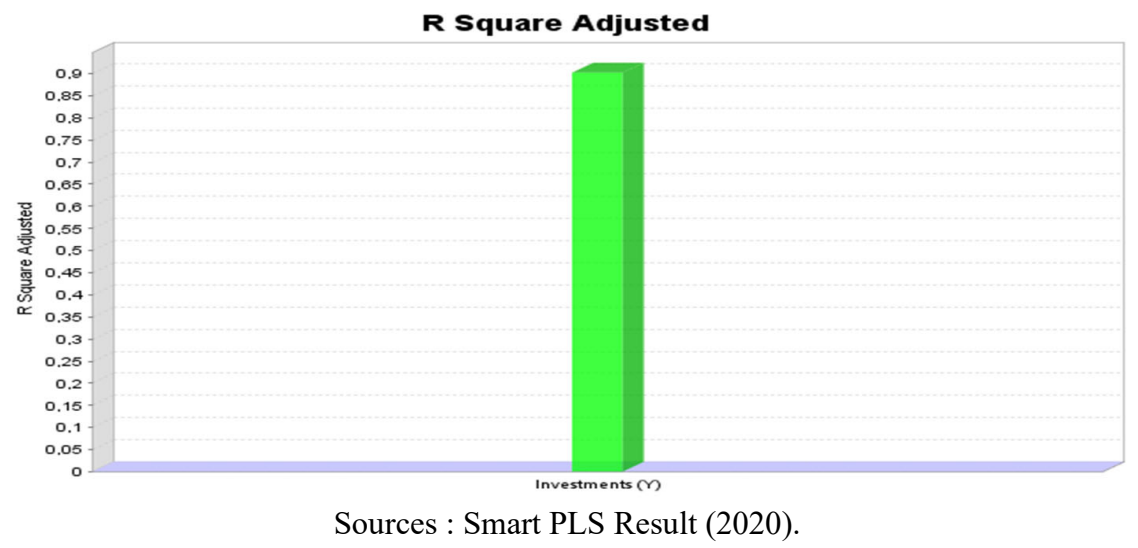

Fig. 2. F Square

Based on Fig. 2, the property of the R-squared value which will be better if you add this variable is the weakness of $\mathrm{R}$ squared itself. The more independent variables used, the more noise in the model and this cannot be explained by $\mathrm{R}$ squared. To cover the weakness of R squared, you can use adjusted R squared. Adjusted R squared has considered the number of sample data and the number of variables used. Adjusted $\mathrm{R}$ squared will calculate each additional variable and estimate the value of $\mathrm{R}$ squared from the addition of these variables. If the addition of the new pattern turns out to improve the regression result model better than the estimate, then the addition of these variables will increase the R-squared adjusted value. If the new pattern of adding these variables shows a result that is less than the estimate, then the adjusted R Squared will decrease in value show in Table 2 as a follows:

Table 2

R-Square Value

\begin{tabular}{lcc} 
& R Square & R Square Adjusted \\
\hline Investments $(Y)$ & 0,922 & 0,902 \\
\hline
\end{tabular}

Sources : Smart PLS Result (2020).

Based on Table 2, the variation of R-Square Adjusted value of 90.2\%. The existence of Population, GDP, Government Sukuk and Sharia Mutual Funds not influence on Investment Sharia Insurance.

\subsection{Discussion}

This shows that are quite potential in reducing unemployment because it absorbs a relatively large workforce (Shahinpoor, 2009; Raditya \& Kassim Salina, 2010; Srairi, 2011; Tahir \& Mark, 2012; Asif et al., 2014; Gnjatović \& Leković; 2019; Doris et al., 2020) One of indicator to see how large an area is absorbing energy work is by looking at some variables that affect demand labor in a company (Srairi, 2011). Small industry development is the way that is considered a major role in the development of the manufacturing industry (Masoud \& Abusabha, 2014; Birkel et al., 2019). The development of small industries will help overcome unemployment problems considering the technology used is labor-intensive technology so it can increase employment and business opportunities, which in turn encouraging regional development and rural areas. The role of the home industry or small industry has a big influence on the economy in Indonesia due to building an industry this small that does not require a large capital and is able to absorb labor. The existence of the financial system plays a very important role in the economy. As part of the economic system, the financial system functions to allocate funds from parties experiencing a surplus to those experiencing a deficit. If the financial system is unstable and does not function efficiently, the allocation of funds will not work well, which can hamper economic growth in a country. Experience shows that an unstable financial system, especially if it results in a crisis, requires very high costs for its rescue efforts. Indonesia experienced instability in financial market conditions during the 1998 financial crisis, at which time the costs of the crisis were very significant. In addition, it will take a long time to revive public confidence in the financial system. The 1998 crisis proved that financial system stability is a very important aspect in shaping and maintaining a sustainable economy. An unstable financial system tends to be susceptible to various shocks, which disrupt the rotation of the economy. The implications of this research are the Indonesian Financial Services Authority (OJK) policy which considers Population, Gross Domestic Product, Government Sukuk and Sharia Mutual Funds for Investment Yield Sharia Insurance in Indonesia. The limitation of this research is to use monthly samples and only observe for 2 (two) years. 


\section{Conclusions}

The results show that Uncertainty Macroeconomic and demographic factors such as Population, Gross Domestic Product, Government Sukuk and Sharia Mutual Funds do not influence Investment Yield Sharia Insurance in Indonesia. Due to the relatively short observation period, this variable is not significant. Whereas population growth in a country is a great potential that can be obtained by a country for the development of an investment.

\section{Acknowledgement}

This study was aimed at meeting the research outcomes in the TALENTA Grant scheme in 2020.

\section{References}

Abas, H., Kawatu, F. S., \& Kewo, C. L. (2020). Analysis of Profit Growth of Manufacturing Companies Listed on the Indonesia Stock Exchange (IDX) for 2013-2017 Period. International Journal of Applied Business and International Management, 72-78.

Abduh, M., \& Azmi, O.M. (2012). Islamic banking and economic growth: the Indonesian experience. International Journal of Islamic and Middle Eastern Finance and Management, 5(1), 35-47.

Abduh, M., \& Chowdhury, N.T. (2012). Islamic banking-economic growth nexus: Evidence from Bangladesh. Journal of Islamic Economics. Banking and Finance, 8(3), 104-113.

Abduh, M., \& Omar, M.A. (2012). Islamic banking and economic growth: The Indonesia experience. International Journal of Islamic and Middle Eastern Finance and Management, 5(1), 35-47. DOI.10.1108/17538391211216811.

Asif, M., Ather, I., \& Isma, Z. (2014). Impact of Islamic Investment Trend on Economic Growth-A Case Study of Pakistan. Research Journal of Management Sciences, 3(8), 8-17.

Birkel, H. S., Veile, J. W., Müller, J. M., Hartmann, E., \& Voigt, K. I. (2019). Development of a risk framework for Industry 4.0 in the context of sustainability for established manufacturers. Sustainability, 11(2), 384-397.

Candelon, B., Ferrara, L., \& Joëts, M. (2021). Global financial interconnectedness: a non-linear assessment of the uncertainty channel. Applied Economics, 53(25), 2865-2887.

Choo, K. S. W., Hussin, M. Y. M., Muhammad, F., \& Chan, P. Y. (2021). The Principles of Malaysia Islamic Real Estate Investment Trust: Contemporary Islamic Core Values. Journal of Contemporary Issues and Thought, 11(1), 97-108.

Cihak, M., \& Hesse, H. (2010). Islamic banks and financial stability. Journal of Financial GCC countries. Review of Islamic Economics. 15(2). 25-60.

Coibion, O., Georgarakos, D., Gorodnichenko, Y., Kenny, G., \& Weber, M. (2021). The Effect of Macroeconomic Uncertainty on Household Spending (No. w28625). National Bureau of Economic Research.

Cui, X., Wang, C., Liao, J., Fang, Z., \& Cheng, F. (2021). Economic policy uncertainty exposure and corporate innovation investment: Evidence from China. Pacific-Basin Finance Journal, 67, 101533.

Doris, A., O’Neill, D., \& Sweetman, O. (2020). Does Reducing Unemployment Benefits During a Recession Reduce Youth Unemployment? Evidence from a 50 Percent Cut in Unemployment Assistance. Journal of Human Resources, 55(3), 902-925.

Elgari, M.A. (2010). Governance standards and protocols on Shariah decision making process. Paper presented at the SCOCIS (Security Commission-Oxford Centre for Islamic Studies) Roundtable in March 2010.

Farahani, Y.G., \& Dastan, M. (2013). Analysis of Islamic banks' financing and economic growth: a panel cointegration approach. International Journal of Islamic and Middle Eastern Finance and Management, 6(2). 156-172. DOI: $10.1108 / 17538391311329842$.

Faruq, A.A.U., \& Ahmad A.B.R. (2009). Islamic microfinance: the evidence from Australia. Humanomics, 25(3). $217-235$.

Furqani, H., \& Mulyany, R. (2009). Islamic banking and economic growth: Empirical evidence from Malaysia. Journal of Economic Cooperation and Development, 30(2).59-74.

Garrouch, K. F. (2021). Explaining the comparative perception of e-payment: role of e-shopping value, e-payment benefits and Islamic compliance. Journal of Islamic Marketing. DOI 10.1108/JIMA-08-2020-0240

Gheeraert, L., \& Weill, L. (2013). Does Islamic Banking Development Favor Macroeconomic Efficiency? Evidence On The Islamic Finance - Growth Nexus. Working Paper 764. Economic Research Forum (ERF). ERF Annual Conference in Kuwait (March 2013).

Gnjatović, D., \& Leković, M. (2019). Contribution of tourist industry to reducing unemployment in the Republic of Serbia. In TISC-Tourism International Scientific Conference Vrnjačka Banja. 4(1). 80-96.

Gössling, S., \& Michael Hall, C. (2019). Sharing versus collaborative economy: how to align ICT developments and the SDGs in tourism?. Journal of Sustainable Tourism, 27(1), 74-96.

Gwadabe, N. A., \& Ab Rahman, A. (2020). The Role of Islamic Finance In Mitigating The Economic Impact Of Covid-19 Towards the Attainment of Maqasid Al Shariah: A Case Study of Waqf Institutions in Kano State, Nigeria. The Journal of Muamalat and Islamic Finance Research, 17(Special Issues), 59-70.

Hohlwegler, O. (2021). The Value of CSR in Times of Increased Policy Uncertainty: Evidence from the Brexit Referendum. Junior Management Science, 6(1), 1-24. 
Jones, P., Wynn, M., Hillier, D., \& Comfort, D. (2017). The Sustainable Development Goals and Information and Communication Technologies. Indonesian Journal of Sustainability Accounting and Management, 1(1), 1-15. DOI: 10.28992/ijsam.v1i1.22.

Khan, M. M., \& Bhatti, M. I. (2008). Islamic banking and finance: on its way to globalization, Journal of Managerial Finance, 34(10), 708-725.

Kumar, L., Hasanuzzaman, M., \& Rahim, N. A. (2019). Global advancement of solar thermal energy technologies for industrial process heat and its future prospects: A review. Energy Conversion and Management, 195, 885-908.

Levy, J. A. (2021). Essays on Uncertainty and Macroeconomic Dynamics (Doctoral dissertation, American University).

Liu, X. (2021). On fiscal and monetary policy-induced macroeconomic volatility dynamics. Journal of Economic Dynamics and Control, 127, 104123.

Malaysia World Islamic Finance Marketplace. (2014). Mutually-beneficial prospects between Islamic finance and economic growth. International Monetary Fund (IMF) World Economic Outlook. Kuala Lumpur.

Masoud, N., \& AbuSabha, S. (2014). Twinkle, Twinkle, Little Star, How Wonder Islamic Finance: Up Above the World So High, Like a Diamond in the Sky. Journal of Sustainable Development Studies, 6(2).294-322.

Morse, K. J. (2020). A Multiple Regression Analysis of Factors Pertaining to Work/Life Balance, Stress, and Financial Well-Being on Life Satisfaction (Doctoral dissertation, Grand Canyon University).

Nobi, M., Al Azhari, M. L. R., Islam, S., \& Billah, M. A. (2020). Comparative Financial Position Analysis of Islamic Banking Industries: A Study of Selected Islamic Banks in Bangladesh. International Journal of Science and Business, 4(11), 119-130.

Patel, P. C., \& Tsionas, M. (2021). Macroeconomic Uncertainty and Risk: Collective Optimism of Small-Business Owners. Entrepreneurship Theory and Practice, 1042258720985475.

Phan, D. H. B., Iyke, B. N., Sharma, S. S., \& Affandi, Y. (2021). Economic policy uncertainty and financial stability-Is there a relation?. Economic Modelling, 94, 1018-1029.

Pospieszna, P., Skrzypczyńska, J., \& Stępień, B. (2020). Hitting Two Birds with One Stone: How Russian Countersanctions Intertwined Political and Economic Goals. PS: Political Science \& Politics, 53(2), 243-247.

Raditya, S., \& Kassim Salina, H. (2010). Roles of the Islamic banks in the monetary transmission process in Malaysia, International Journal of Islamic and Middle Eastern Finance and Management, 3(1), 7-19.

Raza Rabbani, M., Rahiman, H. U., Atif, M., Zulfikar, Z., \& Naseem, Y. (2021). The Response of Islamic Financial Service to the COVID-19 Pandemic: The Open Social Innovation of the Financial System. Journal of Open Innovation: Technology, Market, and Complexity, 7(1), 85-97.

Shahinpoor, N. (2009). The link between Islamic banking an microfinancing. International Journal of Social Economics, 36(10). 996-1007.

Shen, H., Liu, R., Xiong, H., Hou, F., \& Tang, X. (2021). Economic policy uncertainty and stock price synchronicity: Evidence from China. Pacific-Basin Finance Journal, 65, 101485.

Srairi, S. (2011). The comparative productivity change of conventional and Islamic banks. Services Research, 38, 95-113.

Su, C. W., Huang, S. W., Qin, M., \& Umar, M. (2021). Does crude oil price stimulate economic policy uncertainty in BRICS?. Pacific-Basin Finance Journal, 66, 101519.

Tahir, I., \& Mark, B. (2012). Islamic Investment Behavior. International Journal of Islamic and Middle Eastern Finance and Management, 4(2), 116-130.

Warde, I. (2000). Islamic Finance in the Global Economy, Edinburgh University Press, Edinburgh.

Wu, J., Li, H., Zheng, D., \& Liu, X. (2021). Economic uncertainty or financial uncertainty? An empirical analysis of bank risk-taking in Asian emerging markets. Finance Research Letters, 39, 101542.

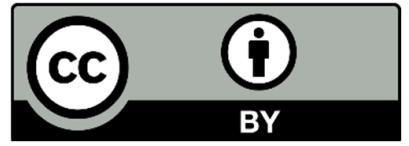

(C) 2021 by the authors; licensee Growing Science, Canada. This is an open access article distributed under the terms and conditions of the Creative Commons Attribution (CC-BY) license (http://creativecommons.org/licenses/by/4.0/). 